\title{
Hidden Sites, Hidden Images, Hidden Meanings: Does the Location and Visibility of Motifs and Sites Correlate to Restricted or Open Access?
}

\section{Inés Domingo ${ }^{1}$ (D) Claire Smith $^{2}$ (D) Gary Jackson $^{2}$ (D) Didac Roman $^{3}$ (D)}

Published online: 14 July 2020

(C) The Author(s) 2020

\begin{abstract}
Using an ethnographic approach, this research assesses common assumptions in rock art research in terms of their validity for Aboriginal rock art sites in the Barunga region of the Northern Territory, Australia. In particular, we assess the potential and limits of the commonly held assumption that open or restricted access to sites and/or the meaning of motifs can be assessed by determining the visibility of the site or image within the landscape. This research calls into question some assumptions that are core to contemporary archaeological method and theory. Our results challenge the notion that a secluded location, or difficulty of access, is needed to restrict access to a site. "Hidden" sites do not need to be hidden, as site access is controlled by a plethora of cultural rules. Moreover, sites that appear to be hidden within the landscape may be open access sites, although access may be restricted for periods of time. Conversely, sites that are visible and accessible from a landscape perspective can be subject to restricted access, regulated through social rules. In addition, the results question the notion that the control of secret information in rock art sites is determined by the visibility and location of motifs and sites. Hidden meanings are not necessarily related to hidden locations or the low visibility of the art, since cultures can have many other ways of hiding meaning. Finally, the results of this study challenge the commonly held dichotomy between sacred/restricted access and secular/open access.
\end{abstract}

Keywords Ethnoarchaeology · Rock art · Theory and method · Semiotics · Aboriginal · Indigenous $\cdot$ Cultural landscapes

Inés Domingo

ines.domingo@ub.edu

Extended author information available on the last page of the article 


\section{Introduction}

In the last few decades, western landscape approaches to rock art have expanded our understanding of this means of visual communication. Along with more traditional analysis of the art (motif and panel description and classification), used to classify and order the artistic record, landscape approaches are providing a more global picture of this heritage by analyzing contextual data beyond the art. These includes physical features from both the natural and the cultural contexts of rock art (see for example Nash and Chippindale 2001; Bradley 2000). Today it is widely accepted that the location and distribution of rock art sites across the landscapes are not at random. While it could be primarily influenced by environmental constraints (availability of caves, rock shelters or other media used as rock art canvas), it is agreed that the main factor in determining rock art location are cultural choices and territorial organization, both shaped by cultural and social traditions and by the function of the art (see discussions in Smith 1991; Bradley et al. 1994; Bradley 1997; Whitley 2001; Ross and Davidson 2006; Engelmark and Larsson 2005; Hartley and Vawser 1998:185; Lenssen-Erz 2004, 2008; Domingo et al. 2008; May and Domingo 2010; David et al. 2011 , etc.). As such, exploring environmental and cultural settings has the potential to inform on the ways space was defined and used: the population size and density of a given area and/or changes in land and site use over time (Domingo et al. 2008). These approaches aim at exploring existing uncertainties regarding: Why were some places selected and not others? Could the sites accommodate a large or a small group? Who was the target audience? Was the art accessible to everyone or was it restricted?

For a long time, the "hidden" location of European Palaeolithic art (most often the dark areas of deep caves) was one of the key features inspiring their description as sacred places or sanctuaries (Reinach 1903; Breuil 1914 and 1952; Leroi-Gourhan 1964). But today, we know Palaeolithic art is also located in the illuminated and inhabited areas of caves, as well as in the open air (Foz Côa, Portugal; Siega Verde, Spain; etc.). These findings gave rise to new questions: Was European Palaeolithic art only restricted when located in the dark? Was the art located in the dark really restricted or even if physically hidden it was known to and maybe even visited by all the members of the group? Were people performing restricted ceremonies at those locations? Or maybe everyone knew that depictions were placed there to maybe protect humans from the dark world? Was the art located in the open air necessarily unrestricted or open to all members of a group?

Today, many of the intangible cultural behaviours and practices related to rock art production and use are hardly visible in the archaeological record. To try to get answers to these and other questions when informants no longer exist, archaeologists have developed a wide set of tools to describe site location (size, visibility, perceptibility, difficulty of access, proximity to settlement areas and established routes, monumentality, proximity to water sources, site capacity and so forth) (Bradley 2000:66 and 2002 Lenssen-Erz 2004, 2008; Ouzman 2005; Lorblanchet 2010; Pastoors and Weniger 2011; Bourdier 2013; Bourdier et al. 2017; Acevedo et al. 2019). These data are analyzed using a variety of methods, ranging from purely descriptive approaches to the tangible features of the places, to mapping (GIS) or to more complex statistical methods (see for example Gillings 2015-statistical analysis to measure invisibility). 
Along with landscape approaches, the internal topography of the sites (distance and openness to view) has been also analyzed to establish the visibility and perceptibility of the motifs in an attempt to deduce the intended audience of particular sites or specific areas within the sites (see Bradley 2000:69; Ross and Davidson 2006; Pastoors and Weniger 2011; Lenssen-Erz 2012; Jouteau et al. 2019). The goal of this approach is to deduce if motifs were intentionally displayed in visible places so everyone could see them or if they were hidden to restrict access to specific people. In the absence of informed knowledge holders, rock art studies use physical descriptors of the place and the landscape to classify the sites according to a range of categories that include public or private, open or restricted, secular or religious and collective or exclusive (Table 1) (see for example Bradley 2000; Martínez García 1998; Fairen 2002, 2004; TilmanLenssen 2007; Bourdier 2013, to name a few). Some of these examples are discussed in detail below in relation to the implications for method and theory in rock art research.

In this paper, we interrogate these archaeological correlations by examining the strategies used by Aboriginal people in the Barunga region of the Northern Territory (Australia) to hide secret meanings and to control access to rock art sites. Within the context of a living artistic system, we seek to determine if the physical features of a site or the particular location of a rock art motif are sufficient to convey information in relation to open or restricted access. The paper illustrates one of the ways in which ethnoarchaeological approaches to rock art can be used to inform and/challenge more purely archaeological approaches and, through this, contribute to strengthening and refining archaeological methods and theories of rock art research.

\section{Ancestral Beings in Living Landscapes}

The research presented in this paper has been conducted in the Barunga region of the Northern Territory, Australia (Fig. 1). This region is characterized by tropical savannah. It contains southern sections of the Western Arnhem Land Plateau and has impressive escarpments that have been used intensively for rock art production. The region is home to a complex and lasting rock art tradition characterized primarily by figurative paintings (Maddock 1971; Chaloupka 1985 and 1993). The art includes naturalistic representations of animals, anthropomorphic figures and their material culture as well

Table 1 Common correlations between site features, site use and potential audience

\begin{tabular}{ll}
\hline Physical features & Site use and potential audience \\
\hline High visibility/openly displayed & $\begin{array}{c}\text { Open-public (this could be applied to sites or depictions that } \\
\text { are easy to view or openly displayed) }\end{array}$ \\
Low visibility/secluded location & $\begin{array}{l}\text { Restricted (this could be applied to sites or depictions that } \\
\text { are difficult to view or consciously hidden) }\end{array}$ \\
Large in size & $\begin{array}{l}\text { Target is a wide audience = Open } \\
\text { Target is a limited audience = Restricted } \\
\text { Emall in size }\end{array}$ \\
Open-public or secular \\
Difficult to access and/or remote location & $\begin{array}{c}\text { Restricted, sacred or private (applicable to both caves } \\
\text { and landscapes) }\end{array}$
\end{tabular}




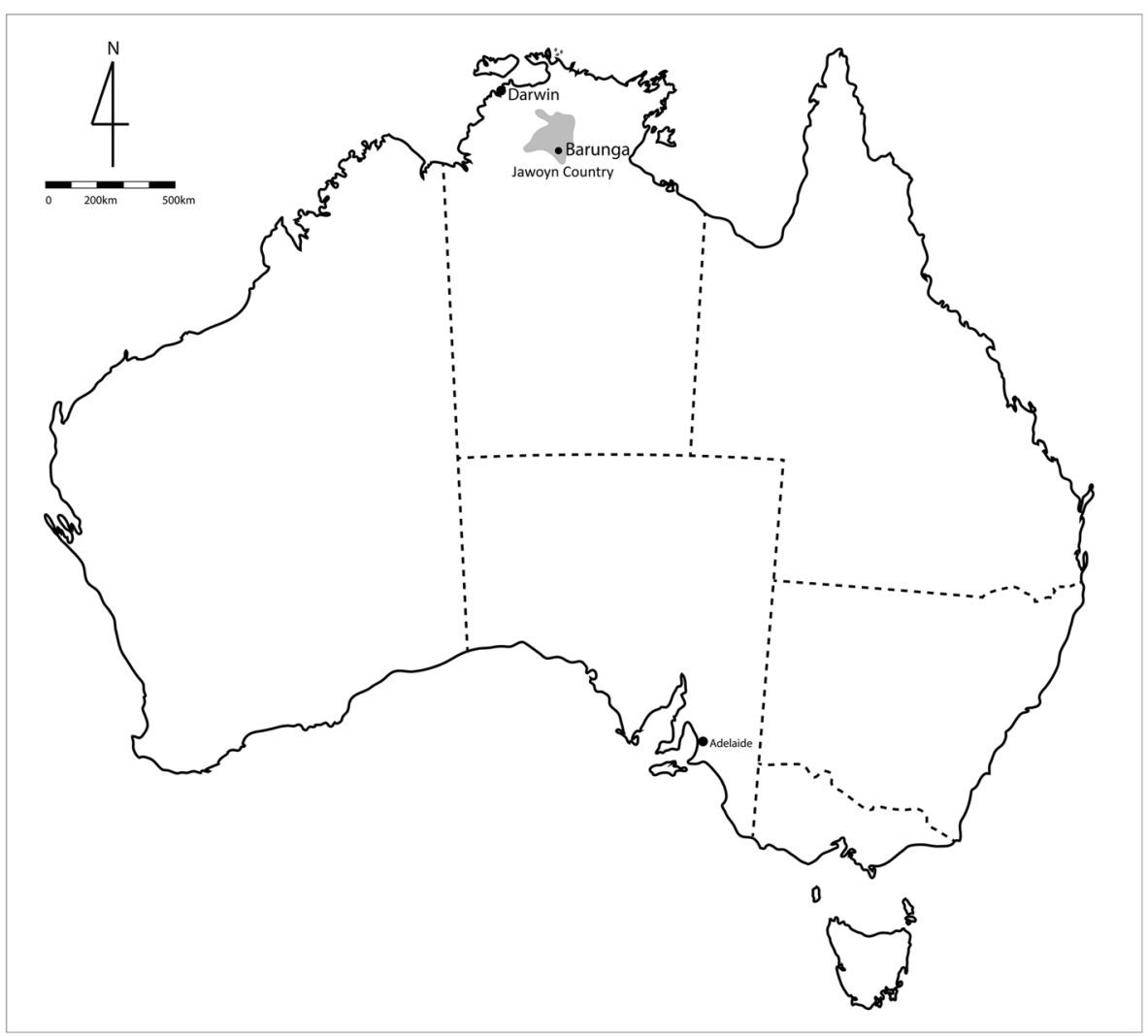

Fig. 1 Location of Barunga in relation to Jawoyn lands

as many narrative scenes produced in different time periods, as shown by the complex superimpositions found in this area. The recurrent use of the same rock shelter over many generations as suggested by changing styles and superimpositions shows that more than the paintings (usually the focus of attention in western approaches to rock art), what is important is the place and the surrounding landscapes where the art is located. These places are symbolically charged and as such, they have been looked after over many generations by performing ceremonies, songs and dances and marking the place with paintings. Seen this way, it could be argued that paintings are more the means rather than an end, used to visually remind and celebrate the cultural significance and powers of particular places, as further discussed below.

Barunga is located on the Bagala clan lands of Jawoyn people. Aboriginal people in this region have a strong connection to specific tracts of land. They know their country as the traditional land of their ancestors. Their dawaro (clan) lands are inherited primarily from father to child. Land is held in perpetuity for the next generation. It cannot be bought or sold. As Maddock (1982:94) observes, land is the common ground between the human members of a clan and the ancestral beings who gave the land its form.

These are living landscapes. Across Australia, Aboriginal people believe that the land was given shape by ancestral beings who travelled across the countryside during the time of creation, also known as Dreaming (Chaloupka 1993). The Dreaming 
explains the creation process, when ancestral beings created the physical features of the land that we see today (Munn 1973; Morphy 1991; Smith 1999). At varying times, and as part of a range of events, the ancestral beings themselves became part of the landscape, by adopting the shapes of rivers, trees, mountains and other natural forms. Sometimes they even placed themselves in the rocks as paintings (Taçon 1990: 30; Chaloupka 1993: 87; Domingo and May 2008). These beings still exist in these places today. They are seen by Indigenous people as powerful and intelligent, with the capacity to hurt those who do not act in the right way (Rose 1992; Merlan 1998; Smith 2004). They can be in different places at the same time. They see everything.

Ethnoarchaeological methods can assist in understanding these landscapes, through highlighting different notions of time and place, as explored by Brady and Kearney (2016):

Many Indigenous people do not have a word for "history", instead understanding the present as a space and time in which ancestors, present generations and descendants all coalesce. It may be that the ancestors lie in the future, instructing the present generation in how to live, thereby reconfiguring the future as an aspirational present. It might also be that ethnoarchaeology and what it seeks to produce have greatest relevance when imagined through the lens of cultural identities which are constantly emerging, and which are dependent on knowledge that is constantly being produced and refined (Brady and Kearney 2016: 651652).

Some of the places inhabited by ancestral beings are visually commanding. As discussed by Taçon (1999), certain natural places that are unusual or outstanding may "invoke common responses in human beings - feeling of awe, power, majestic beauty, respect" and so forth. These include places resulting from great natural transformation: mountain ranges, volcanos, steep valleys or gorges; junctions or points of change between geology, hydrology and vegetation; unusual landscape features (peaks, caves, holes) or places providing panoramic views (Taçon 1999:37). Taçon suggests that for Aboriginal people in his study area, those places are significant because they are powerful and related to creation times, creation beings and creation actions. Some places are considered so powerful that it would be dangerous for noninitiated people to approach them (Taçon 1990: 12-13). In the Barunga region, there are sites that are so potent that they can only be visited by two senior men together, one from each moiety. Even visiting secular sites can be dangerous. This danger is mitigated by "calling out" to the ancestors when arriving at a site, seeking permission to visit (Smith 1992). In Western Arnhem Land, Aboriginal people from the Kurulk clan do not collect white pigment in their own clan lands during the wet season to avoid disturbing the king brown snake ancestral being. However, if it is necessary to collect this material during this time of the year, the cultural custodian/junggayi for this place can make this safe by talking to this ancestral being (Taylor 1996: 59-60). At other places, "correctly conducted rituals or observances, such as rock painting, songs, ceremonies, and blowing water allow individuals to tap into the power of places or to be protected from it" (Taçon 1990:13). As Brady et al. (2016) argue, researchers should focus on the wider social context of rock art, including the affective nature of 
motifs and the networks of relationships within which these motifs are embedded. This wider, more holistic approach to rock art interpretation has the potential to provide clearer insights into notions of change, continuity and relevance.

Often, the creation of rock art is entwined with creation stories and places. Rock art motifs are not a static and inert representations. Instead, they are potent images that "continue to express and generate concepts of relatedness and which ultimately lead to discussions of a non-human-centred landscape that is premised on attributions of intentionality, obligation, responsibility and reciprocity" (Brady and Bradley 2014:157). This is important for this paper since these beliefs on the power of the spirits alive in the landscape constrain the mobility of the people. Every person will be told where they can go, and where they cannot. And people going to a new area will be always escorted by an Elder, who can tell them where they can or cannot go. This is done to protect people from the spirit beings that continue to live in the landscape (Jackson and Smith 2005). Conformity is ensured through the fear that transgressing these rules will result in punishment by spirit beings. In the old days, this was reinforced by the fear of death (execution) by traditional law men (Smith 2004).

\section{Assessing Site and Motif Accessibility Through Size and Visibility}

In this section, we assess the correlations commonly assumed in rock art studies, as outlined in Table 1, in terms of our ethnoarchaeological research in the Barunga region, Northern Territory, Australia. Claire Smith and Gary Jackson have conducted rock art research with Aboriginal people in the Barunga region since 1990 (see Smith 1992, 2004). Ines Domingo and Dídac Roman first came here to conduct research in 2001 and 2007, respectively.

\section{Hidden Sites}

One of the major assumptions of many current western landscape approaches to rock art is that a secluded location, or one that is difficult to access from a physical point of view, is likely to indicate restricted access to a site. Conversely, a site with high visibility within the landscape is likely to indicate unrestricted access to a site (see Bradley 2000:69; Ouzman 2005:9; Pastoors and Weniger 2011; Lenssen-Erz 2012; Jouteau et al. 2019). Our ethnographic research offers two insights that question the ubiquitous applicability of this correlation.

Firstly, while sites that are clearly visible and easily accessed may be public sites in day-to-day contexts, access to these sites can become restricted while a ceremony is in progress. Important ceremonies can be held over several months. This is the case for the rock art site known as Jerraewun, north-east of Barunga. Moreover, not all hidden sites are subject to restricted access. The site of Doria Gudaluk (also known as Beswick Creek Cave) is an iconic rock art site in Australia (Elkin 1952; Macintosh 1952 and 1977; Gunn and Whear 2007). It contains around 160 motifs, comprising 153 figurative paintings and seven concentrations of engraved lines, circular holes and areas with abraded surfaces (Smith et al. 2016). The site could be considered as hidden from a landscape perspective considering the physical location and its overhanging structure. The visibility of the site is low both from the top and the bottom of the escarpment, even if the site is large (around $44 \mathrm{~m}$ long, $7 \mathrm{~m}$ wide at the dripline and $10 \mathrm{~m} \mathrm{high}$ at the centre). 
(Fig. 2). Aboriginal people considered it a good place to hide. During the 1940s, 1950s and 1960s, in particular, light-skinned Aboriginal children were forcibly removed from their families and brought up in institutions, in what is known as the Stolen Generation. During this period, Doria Gudaluk was used as a place to hide children from policemen or patrol officers who were mounted on horses (Smith 2004; Smith et al. 2016). What this particular site and accounts exemplify is that the concept of hidden is complex and mutable and it will depend more on the knowledge of the natural and cultural landscape one has, than on the physical features of the place.

Moreover, until the 1980s, Doria Gudaluk was used as both a ceremonial site and a place that could be visited by local Jawoyn families, especially during the wet season (Smith et al. 2016). This is another interesting point for rock art researchers since the same site combines both public and private domains, rather than these domains being mutually excluding and opposed. As such, this example illustrates the ambiguous boundaries between public and private (sacred and profane, symbolic and utilitarian) domains in rock art (see, for example, Bahn 2010:152-156), and in life in general (Strecker 1988). This illustrates how challenging it is to identify these two spheres through archaeology by relying mainly on the physical features of the place and the landscape.
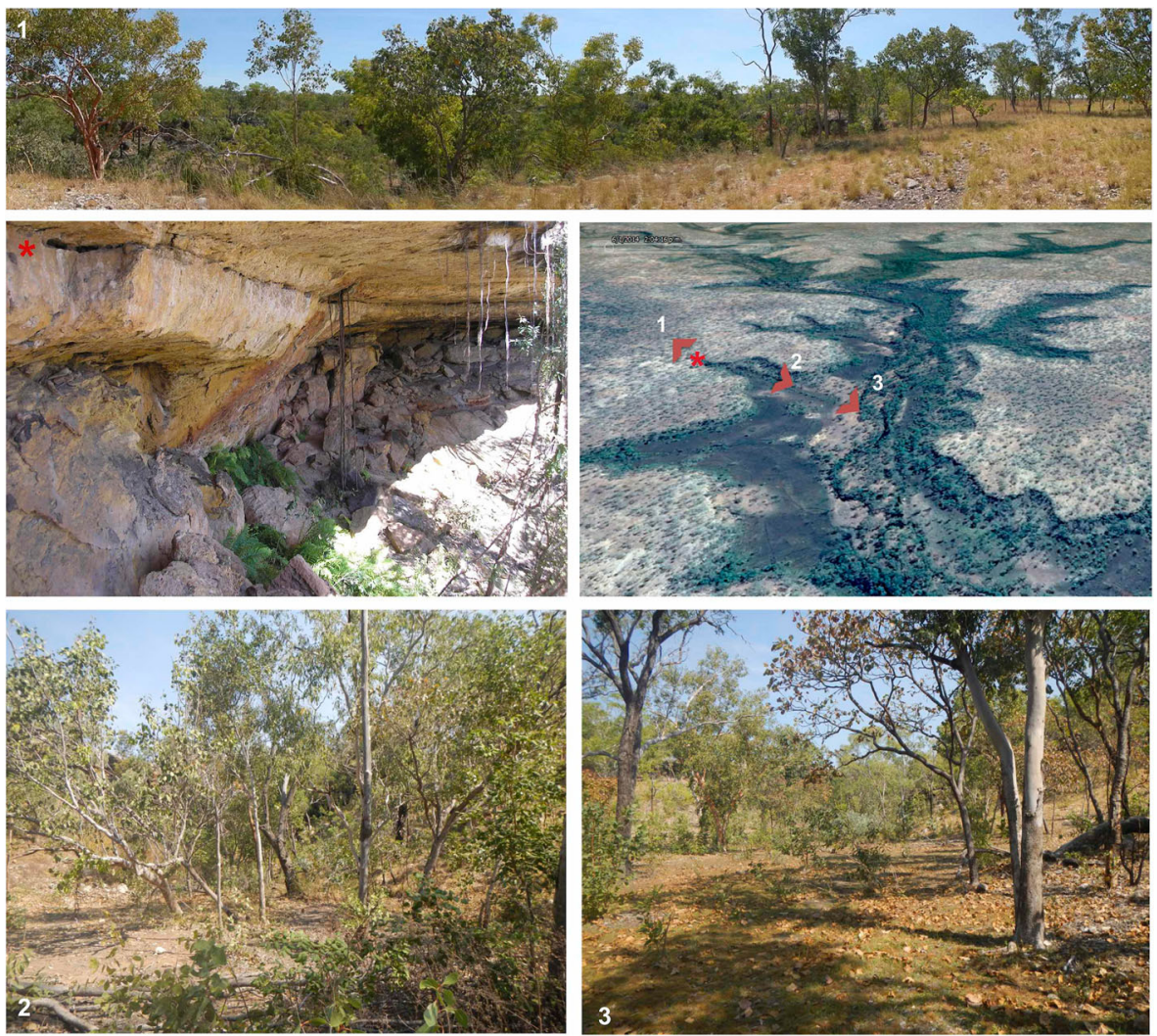

Fig. 2 Landscape of Doria Gudaluk 
Aboriginal people in this area practiced various levels of seasonal mobility until the 1940s and 1960s. During these times, the site was visited regularly. While it is generally open to men, women and children, the physical structure of this site, as previously discussed, made it suitable for hosting secret ceremonies as well. Ceremonies were held during the wet season, between November and March, when the site served as a shelter from the rains. Up until the 1980s, Doria Gudaluk was the place where important women's ceremonies were held (Phyllis Wiynjorroc pers. comm. 1992). At such times, it was closed to general visitation (Macintosh 1952; Smith et al. 2016). Thus, the same site was both open and restricted at different times of the year and in different contexts. Today, it is impossible to make a clear distinction between both functions based on the archaeological remains preserved at the site.

Doria Gudaluk is also interesting because it is an example in which different, related ceremonial activities occur in different locations, both on-site and off-site. While ceremonies associated with rock paintings occur at the rock art site, the major ceremonial grounds are not located within the site but in the surrounding landscape. This may be related to the structure of this particular site, as there are few flat areas on the site floor where a number of people could stand together. In addition, Doria Gudaluk is part of a wider network of related ceremonial locations. Aboriginal ceremonies are complex affairs that are critical to the continued wellbeing of society. As such, they are normally conducted by a group. Ceremonies may involve several locations as part of a single ceremony. Different actions relating to the same ceremony can take place in different places. Some actions are undertaken by men alone, some by women alone and some by men and women together. Because ceremonies are group activities, ceremonial grounds need to have an open space to fit a large number of people, both performers and, when appropriate, audience. In addition, ceremonial grounds need to be close to water. At Doria Gudaluk, the rock paintings are not visible from the ceremonial grounds. Also, ceremonies can leave no physical evidence at that place, other than dirt that has been compressed by stamping feet while dancing. An example of this is shown in Fig. 3, which records a mortuary ceremony for Billy Lukanawi, held at Weemol in central Arnhem Land. So, contrary to what is often assumed in western archaeological

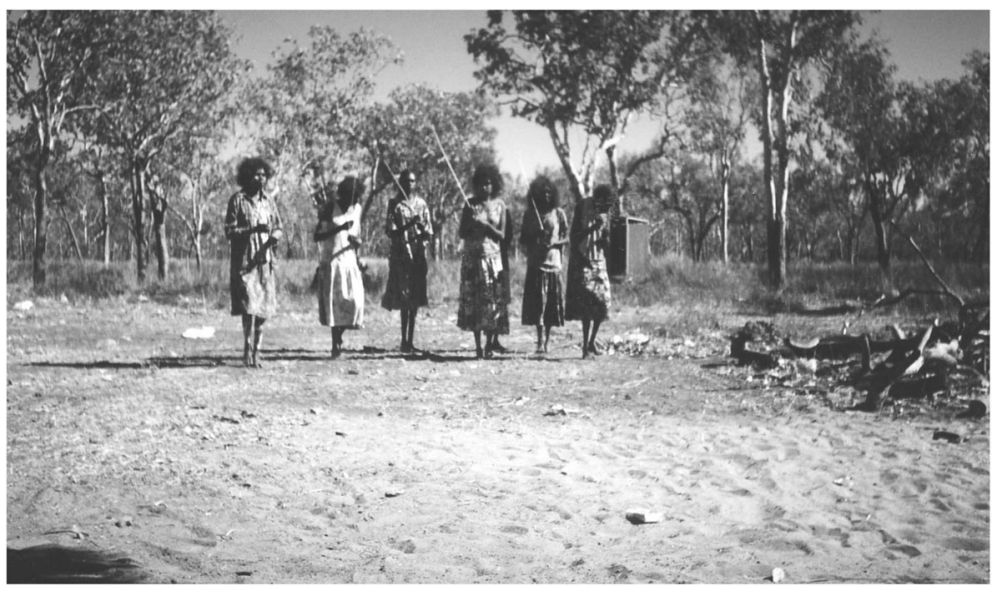

Fig. 3 Ceremonial dancing at the funeral for Billy Lukanawi, Weemol, Central Arnhem land, 2001 
approaches to rock art, ceremonial grounds are not necessarily the rock shelters, where the paintings are located, but may be in the surrounding landscape. While some aspects of ceremonies, such as the repainting of images, may occur in a rock shelter, other aspects, such as dancing, may occur away from the shelter and leave scant archaeological evidence. This challenges the possibility of identifying ceremonial spaces based on the size of the painted site or the archaeological remains identified within a site or in the surroundings.

Secondly, the major way in which access to sites is restricted is through cultural controls on visitation, which do not leave archaeological evidence. During the 30 years that we have worked in the Barunga region, we have been allowed to visit less than 20 sites. However, this does not indicate a dearth of rock art sites in the region. By 2010, an inventory conducted by the Jawoyn Aboriginal Association over several years in the early 2000s had identified 117 site complexes, 921 sites and more than 44,000 individual artworks on Jawoyn lands (David et al. 2011: 75; Gunn et al, 2011). The Jawoyn Aboriginal Association was working under a remit from traditional owners to record the location of sites across the entirety of Jawoyn country for future generations.

Although the area encompassed by the Jawoyn language group is a much wider expanse that includes Bagala clan lands, it is also true that there are many rock art sites on Bagala lands that the authors of this paper have not been allowed to visit, nor are they allowed to conduct rock art surveys on Bagala lands. Given that there are thousands of sites on Jawoyn lands, why is our access to rock art sites so limited, even after 30 years of working with the community every year? First, Aboriginal people in the Barunga region believe that the spiritual beings guarding some sites are so dangerous that if the wrong people went there, they would be harmed, or even killed. They divide the world into two moieties that encompass people, land and animals (Fig. 4) (Elkin 1950; Maddock 1971; Taylor 1996; Berndt and Berndt 1999; Smith 1999). Some sites are so powerful that they can only be visited by two Aboriginal people together, one from each moiety. Second, Aboriginal knowledge is an economic resource. This includes access to sites. Third, we have never asked to access additional sites. While our research started an ethnoarchaeological study of Aboriginal artistic system, our over-riding longterm strategy has been to let Aboriginal people lead the research as much as we can, and to see the directions in which they take us. Over time, this has oriented our research towards heritage, health and wellbeing (e.g. Smith et al. 2020). Within this broader context, rock art sites have remained core to our research. All of the sites we have visited have been selected by Aboriginal people as appropriate for visitation. Our site visits are always supervised by cultural custodians/junggayi. While it is possible that additional sites could be selected at some time in the future, after 30 years, our view is that we have seen all the sites in this area that we are meant to see.

There are many controls over physical access to sites. There are sites that are restricted to men only, and sites that only women can visit. Some sites are so powerful that they can only be visited by two people together, one from each moiety (discussed above). Some sites are normally open to all but are closed when ceremonies are being held. This is the case with Doria Gudaluk, and with other sites in the region. In the contemporary world, one of the major ways in which access to sites is controlled is by the stipulation that sites are only visited under the supervision of a junggayi. In this region, the junggayi is the traditional custodian of a particular area, responsible for 


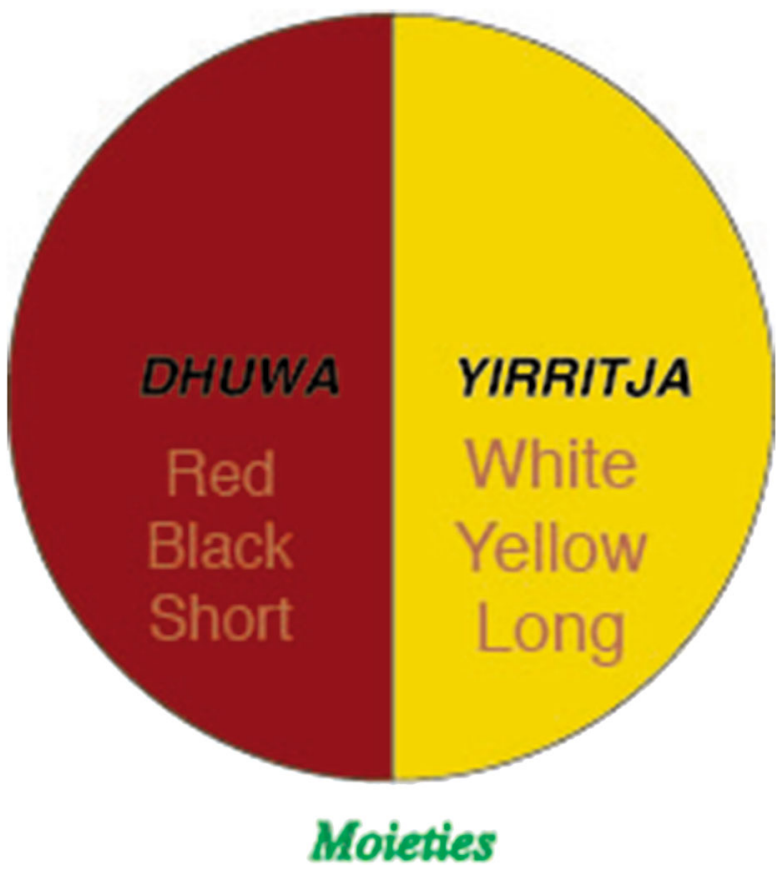

Fig. 4 Duwa and Yirritja moieties, Barunga region, Northern Territory, Australia

looking after culture and country under the oversight of the Traditional Owner (Smith 1992). This has been the convention since European researchers first visited the region, as is demonstrated in these sections from a paper by N.G.W. Macintosh concerning his visit to Doria Gudaluk with A.P. Elkin in 1951:

On Sunday, the 25th May, Lamderod and another native, a senior Ngalpun named Charlie Mangga, aged about 48, took us to the cave ... On Wednesday, 28th May, the author returned to the cave, guided by Charlie Mangga ... Charlie Mangga would not at any time leave the author alone in the cave, and stolidly watched every movement during the recording of the paintings; at the termination of the work he said "you all finish now" and ushered the writer out, having a final look round himself before departure (Macintosh 1952: 256-261).

That tradition continues today. Whenever they visit a site, the authors of this paper are accompanied by community people. Usually, the senior Aboriginal person will call out to the ancestors in an Aboriginal language, usually Jawoyn or Ngalkbon, letting them know that they are visiting the site (see documentary footage in Smith 1992). This is a way of seeking the ancestors' consent and of inducing the ancestors not to harm visitors, especially those with whom they are unfamiliar.

Often, when we visit sites, we are accompanied by a whole family, and the site visit connects children to their ancestral heritage. As Kearney, Brady and Bradley (2017:365) point out, "children being active on country keep country happy and healthy. These activities are a part of "lifting country up" and remaining emotionally 
engaged with a place". In rare cases when the junggayi is not available, another senior Aboriginal person will be delegated to take on this supervisory role. This rule protects both the site and the system of knowledge. Moreover, it protects the researcher from rumours that they are wandering the landscape unescorted with the attendant possibility that they could be visiting restricted sacred sites. This is one essential component of a range of intellectual property acknowledgements that inform our long-term research with the Barunga community (see Wiynjorroc et al. 2005; Jackson and Smith 2005; Smith and Jackson 2008).

In European archaeology, we tend to consider that the important place is the rock art site where the paintings are located. However, in the Barunga region, rock art sites need to be understood within the wider landscape. Sometimes, they overlook restricted areas or ceremonial grounds. Although the rock shelter can be small, the area where the ceremonial activities are performed may not be the shelter itself but the surrounding landscape. As also pointed out by Taçon, rock art may overlook sacred or restricted areas, indicating the approach to sites or marking their limits (Taçon 1999: 40). One of us (Gary Jackson) was once told by the traditional custodian Peter Manabaru to "look for a ceremonial ground" in the surroundings. Such an appreciation highlights the need to move away from a focus on the precise location of the art to achieve a more global understanding of the landscapes where the sites are located to identify other places potentially linked to rock art production and uses. Moreover, there is not a clear relationship between the size of the audience (number of participants according to the space available) and the size of a rock art site. While rock art can be produced at important or powerful places, it may be located in the surroundings of the places that are the foci of power, as in Billy Lukanawi's mortuary ceremony mentioned above.

Some cultural controls apply to both physical access and access to knowledge. Sometimes, a site or a place may be clearly visible, but the deeper levels of cultural knowledge are hidden. For instance, the Milk Dreaming site (Fig. 5) can be clearly seen from the road between Barunga and Beswick. It is common knowledge that this hill is

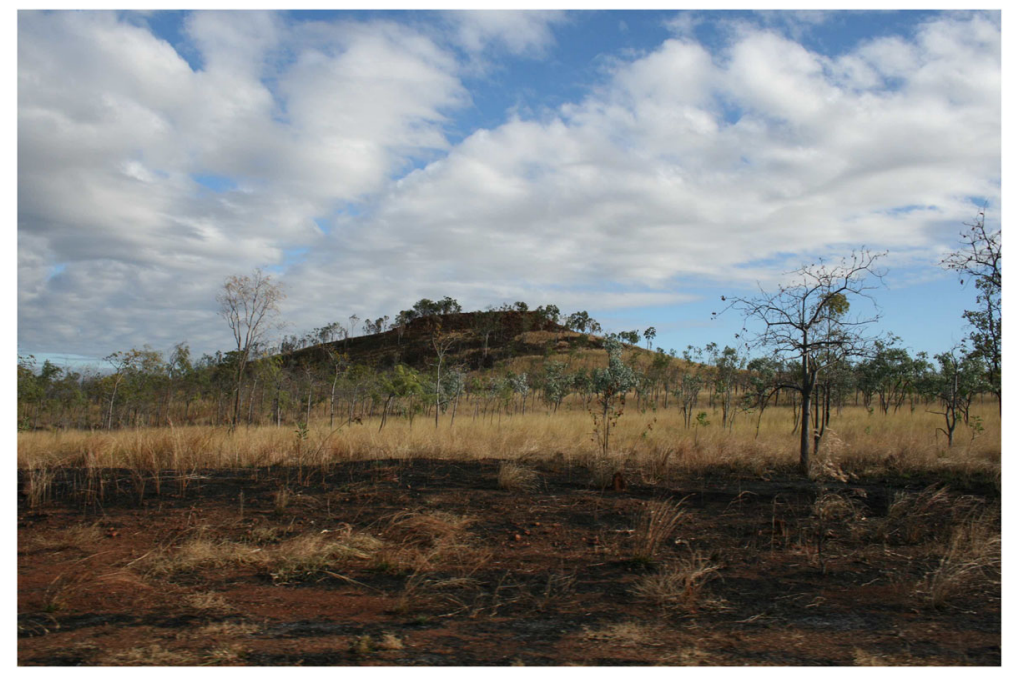

Fig. 5 Milk Dreaming site 
the physical embodiment of the breast of an ancestral being who was a young girl. However, there are many levels of restricted knowledge associated with this place, and this knowledge is closely guarded. While the physical access is easy, it is strictly controlled from a cultural point of view, as a way of protecting people from the power contained in this place, and the harm that could be caused to anyone who goes there without the appropriate cultural rights and knowledge.

\section{Hidden Images}

Some current western approaches to rock art link images hidden in a secluded location to restricted access and/or knowledge (e.g. Lenssen-Erz 2012; Jouteau et al. 2019). Tilman Lenssen-Erz, for example, has developed a sophisticated model for collecting contextual data relevant to rock art in which he argues that:

'Private presentation' of pictures means that the display is in a secluded configuration which does not allow many people to see it at one time; sometimes pictures may even be so hidden that it is impossible even for a single person to see them properly. For such pictures, a different kind of use and function can be assumed to have existed, as opposed to the "public" ones which are openly displayed in places where crowds of people could gather to view them (LenssenErz 2012:53).

While this aspect of our study is based on limited data, this link between restricted information and hidden images is confirmed by our research. Our interpretations should be understood within the context of our access to information, as described earlier in this paper and detailed below. In the Barunga region, sorcery motifs, which are created with the intention of harming or killing someone, may be physically hidden from view. An example of this is evident at the site of Drupni. This is a large rock shelter, $80 \mathrm{~m}$ in length and around $10-12 \mathrm{~m}$ in width. It is known as a family site, a place where families would camp during the wet season, when it rains heavily every day. Within the ethnographic past, it was inhabited by men, women and children, the latter evidenced by hand stencils the size of children's hands. There is also evidence of hearths, grindstones and stone artefacts.

The entrance to this site is along a narrow walkway beneath the escarpment. There are a few paintings on the rock walls along this walkway. At one point, there is a small overhang low to the ground. The interior part of the overhang contains a depiction of malinji, a spirit thought of as mischievous or dangerous in the Barunga region. For example, they can trick people and turn around the landscape so people get lost. The image painted inside this overhang is a human-like figure that is depicted upside down. Gary Jackson first located this image in the company of Jack Chadum, Peter Manabaru and Billy Lukanawi. When he was shown this image, Jack Chadum said "This is the one, Malinji", to indicate that this is a true depiction of a malinji. This depiction is hidden from general view as it can only be viewed by lying on the ground.

Moreover, in this case, the hidden location of this dangerous spirit marks the physical dangers of this particular part of the site: one of us (Ines Domingo) was bitten by some kind of insect while taking a photo of this image, after previously being warned by an Indigenous Elder that taking this photo could harm her. The following 
interpretation highlights the sense of this being a living landscape in which creatures can work with humans to protect the landscape:

Those old people gave permission to take that photo, but that bite was a warning that only the researchers can look at that painting. That bite will help to find that person, like a scent, if they publish that photo. If the photo is published, old people are going to talk to the researcher. They will get punished for not respecting Aboriginal culture. Probably they cannot work with our community any more, and other Aboriginal groups will know not to invite them to their country because they will do the same thing to them (Isaac Pamkal pers. comm. 16 June 2019).

Although we have obtained permission to publish the malinji image in the past (Domingo et al. 2016), when we sought permission for this paper, the person who had given permission, Peter Manabaru, had passed away. The view of current custodians is that publishing this image might be dangerous. For this paper, we were given permission to publish a tracing of the image (Fig. 6). This change in permission is one manifestation of a dynamic, living tradition that is continually re-interpreted by the custodians who are responsible for the safety of the community.

What is the social and cultural significance of this hidden malinji? At one level, it changes the experience of people who are visiting the site. For people who are unaware of it, the site is a place of safety and pleasure. It is a place for families to stay out of the rain and a place to tell stories of ancestors and forebears, and of daily activities. However, for those who are aware of the malinji, the site is a more perilous place, one with an undercurrent of danger. Thus, different people visiting this site will have different experiences. It is possible to interpret the hidden location of this painting as a warning that this space is physically dangerous due to biting insects. However, in our view, this does not hold as the warning cannot be obtained until the painting is viewed, and this can only be done through physical contortion.

Finally, we note that while the sorcery image at Drupni is physically hidden, there are other examples within the wider region where it is not clear whether sorcery motifs are hidden or in public view. What is clear, however, is the power that Aboriginal people attribute to sorcery motifs within a living landscape (e.g. Mulvaney 1992; Taçon 1994). Rose (1992:67) records an example in the Victoria River Region, west of Barunga, when a sorcery motif was inscribed on a boab tree. Alan Young, the Aboriginal man with whom Rose was working, was responsible for that particular tract of country. When he saw the image, he went to some trouble to try to identify the intended victim and, when he had done this, to prevent the killing by scraping away the image and asking the ancestral being associated with the site, the Black-Headed Python, not to harm anyone. Brady and Bradley (2016) record a similar incident concerning a sorcery motif in the rock art of the southwest Gulf of Carpentaria, located to the south-east of Barunga. In this instance, an Aboriginal man became aware of a rock art sorcery image and tried to rub it out to prevent the killing. However, he was unsuccessful, as he was too late and "too much of the paint had gone too far into the rock" (Brady and Bradley 2016:896). Brady and Bradley argue that this example shows how "the relational is embedded within the ontological and epistemological nature of 


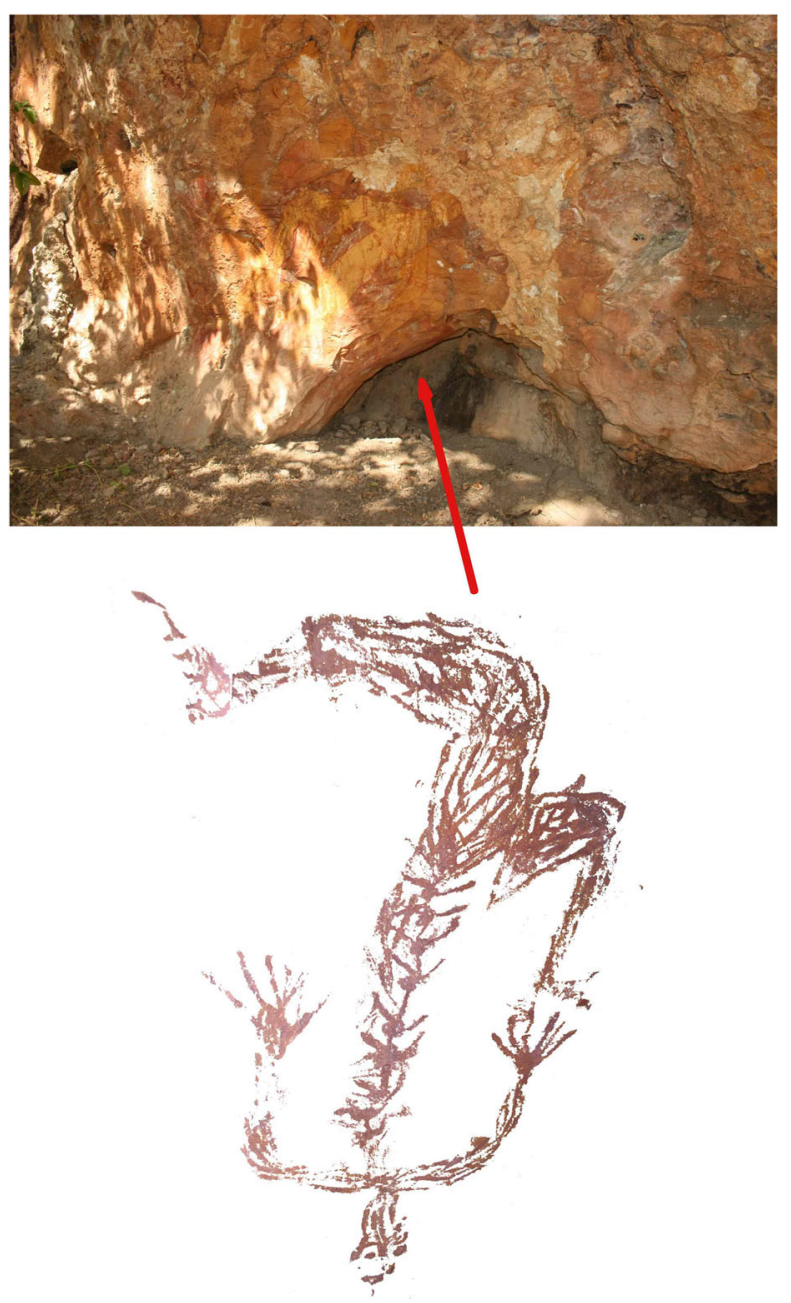

Fig. 6 Location of the malinji image

[the site of] Kurrmurnnyini, and it is only the praxis of a site that allows one to understand its power and significance" (Brady and Bradley 2016:896).

\section{Hidden Meanings}

One important assumption in western approaches to rock art that we assess in this research is that large or visually dominating images, especially those in central locations within a site, contain open access information since they can be viewed by a public audience, while restricted or secret meanings are likely to be associated with images that are not on clear visual display (e.g. Fairen 2002, 2004; Lenssen-Erz 2004, 2008; Jouteau et al. 2019; Bourdier 2013).

We have found that whether they are physically hidden or not, images in Aboriginal art often are multivocal and associated with hidden meanings. In his landmark analysis 
of the art of the Yolngu people of north-east Arnhem Land, Howard Morphy (1991) explores the multivalency of images and the ways in which information is secreted within paintings that may well be displayed within a public context:

... the same design could have a multiplicity of meanings associated with it in different contexts. The designs themselves are multivalent, signifying clan, place, ancestral event, and so on. The same design may encode a number of different ancestral events, and the specified referential meanings of the geometric elements may vary according to the particular interpretation focused on. In order to interpret the geometric components of a painting one has to know not simply what the signifying potential of the elements is, but which signifieds apply in the context of the particular painting. The system functions to restrict the amount of information imparted through the mere revelation of the painting and enables the secrecy of its meanings to be maintained ... The geometric art ... both conceals and accumulates meaning.

(Morphy 1991:191-193)

While Morphy's study highlights the multivalency of images in Yongu bark paintings, the basic tenets concerning the protection of knowledge apply across most, if not all, Aboriginal knowledge systems in the Arnhem Land region (see Taçon 1989; Taylor 1996; May 2008:171-194; Smith et al. 2016), and probably across Australia. In the Barunga region, both figurative and geometric images can be multivalent. The same motif may have many levels of significance and some levels of knowledge are open only to initiated people. Information is released to the new generations on the basis of their age, gender and personal qualities (such as respect for culture). The many meanings of rock art (and other aspects of culture) are unfolded and amplified during a person's life, with new meanings providing deeper understandings of previous meanings. As Davidson (1999: 130) points out, meanings are not fixed, even within the lifetime of the artists. And influences would have changed between groups over time and place, and even in relation to different artefact types (Hayward et al. 2018: 10).

Many rock art motifs hold secret information. These motifs can be placed in open locations with high visibility. For example, the Luma ancestral being depicted in Fig. 7, is a large, dominating motif within the site of Doria Gudaluk. While there is a level of public knowledge relating to this ancestral being's travels during the creation era, there are many levels of restricted knowledge. Some of these layers of knowledge are gendered, with the information available to only senior males or senior females. At this particular site, secret women's knowledge and secret men's knowledge co-exist, and this knowledge is activated by a single motif, the Luma figure.

Another, different image at this site contains highly secret women's information. We do not have permission to show this painting, even as a drawing, as it is a powerful image that could endanger the health of men who see it. In this case, Aboriginal people have developed two ways of restricting/protecting knowledge. First, the power of the image is hidden through a failure to identify its meaning and significance. Although he visited Doria Gudaluk many times with traditional 


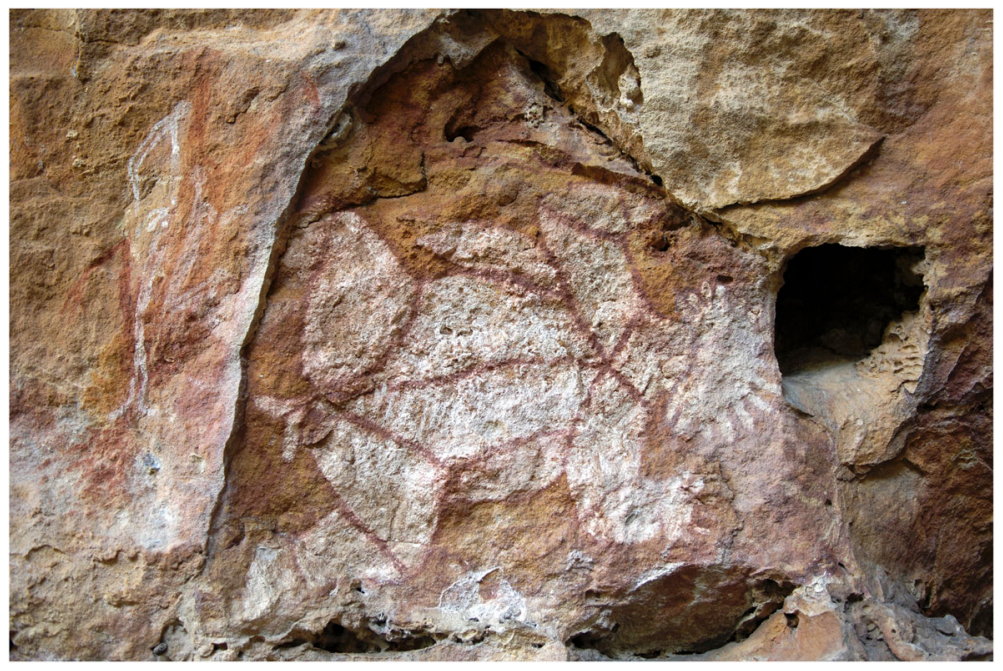

Fig. 7 Luma Luma ancestral being

custodian, Peter Manaburu, Gary Jackson was not instructed to avoid looking at this image. This is because Aboriginal people realize that there is some risk in identifying a place, a tree or a motif as highly significant. They reason that if they do not draw attention to this particular image, visitors to the site will treat it in a cursory way as one of many other motifs at this site. This way of protecting people from the impact of powerful knowledge applies to both motifs and places. High visibility does not necessarily imply that the meanings associated with a motif are open or public knowledge. This is also true for Indigenous sites such as trees or quarries.

While the "don't draw attention to it" strategy works well for non-Aboriginal people and occasional site visitation, the danger posed by men looking at this motif becomes much greater if people are camping at the site, as they did in the past, up until the 1980s. In these situations, a second strategy is invoked to protect Aboriginal men from the dangers of looking at this motif. When they visit this site, Aboriginal men are informed that looking at this image could make them sick. This warning is part of a wider system of control over where an individual can look. In places where there are restricted men's sites, women are instructed to not look in that direction. This makes sense on many levels. It curtails curiosity, which protects the individual from rash actions. In addition, it reinforces the power of the land through the continued presence of ancestral beings and the authority of custodians.

The examples discussed illustrate that neither the site location nor the size of the motifs necessarily reflect whether an image is secret or sacred, with hidden meanings. Using western landscape approaches, both these images would be considered as open and addressed to a wide audience as assessed by their large size, central location and wide visibility. Ethnographic information demonstrates that physical features may not necessarily reflect whether access to information encoded in an image is restricted. This warns the limits of purely archaeological approaches to rock art. 


\section{Implications for Method and Theory in Rock Art Research}

The analysis presented in this paper challenges some of the methodological and theoretical assumptions that are taken-for-granted in western approaches to rock art. Accordingly, the individual insights discussed here can be used to rethink some of the theoretical and methodological approaches to understanding rock art research in Europe and other parts of the world. The features outlined in Table 1 have been drawn on by different scholars to suggest different categories of sites and propose different site uses (see for example, Bradley 2000; Martínez García 1998; Fairen 2002, 2004; TilmanLenssen 2004, 2008). According to Bradley (2000), the proximity between settled areas and rock art sites in places like Scandinavia, southern Scotland, north-west Spain and northern Italy indicates that they were easy to access. Moreover, he considers that it would have been easy to prevent unauthorized people from seeing sites when they were located in remote areas, due to the difficulty of accessing these sites and because they could not accommodate many individuals.

Criado (1993) used similar categories to define a range of visualization strategies in Spanish prehistoric art ranging from hidden (considered more characteristic of Palaeolithic rock art), to monumental strategies (more typical of postglacial art located in the open air). Nevertheless, the discovery of Palaeolithic rock art in the open-air in the 1980s and 1990s broke this dichotomy (Palaeolithic art =cave art $v s$ postPalaeolithic art $=$ open air) and marked a turn in the interpretation of this art (Balbín Behrmann and Bueno 2009), opening new perspectives to explore the potential functions of this prehistoric means of visual communication. Pursuing similar lines, Fairen (2002) analyzed the physical settings of post-palaeolithic rock art in Mediterranean Spain to deduce territorial control and use strategies. For example, she considered the wide visibility of some Macroeschematic rock art sites located in open air rock shelters and the characteristics of the motifs (large and very showy) as signs of a conscious way to transform spaces into monuments. In addition, she interprets these places as related to transit areas. Similarly, she describes smalls sites with difficult access as restricted places and large sites with easy access as aggregation sites and thus as open or public (Fairen 2004).

In Namibia, Lenssen-Erz $(2004,2008)$ used an equivalent approach to suggest seven site classes with different use patterns. These range from long- to short-term sites, from large to small, with either secular or ritual purposes. He also identified sites used as landmarks related with pathways. While conscious of the limits of working in a noninformed context, he considers this method useful to reconstruct mental maps for past peoples and to discern the motivations behind the actions and behaviours of humans. In the same way, but applied to a specific site, the outside location and large size of the Palaeolithic site of Roc-aux-Sorciers rock shelter are interpreted by Bourdier (2013) as evidence that the site was open, collective and thus it was meant to be seen. These are but a few examples.

While approaches to rock art that look beyond the pictures have certainly improved our perception of past forms of art, especially in places where non-informed methods are available, some aspects of these dominant interpretations can be challenged through ethnoarchaeological observations. Our western archaeological approach to rock art locations can overlook the complexity of human cultures, where access to either the sites or the knowledge behind the sites, the compositions or the motifs can be restricted 
through cultural regulations that go beyond the difficulties of accessing a particular site, composition or motif or their level of visibility. As suggested by Bahn (2010:138), "such phenomena will always remain an intangible factor in our reconstructions of the remote past", since these sorts of cultural constraints are usually archaeologically invisible. However, they should be kept in mind if we are to develop more effective empirical approaches to the past. Thus, while open visibility could suggest that the site, the composition or the motif may be aimed at a wide audience, we cannot categorically reject a more private function for the site and/or the art. Our study promotes a rethinking of engraving sites that are located in clear view, such as those of Côa Valley in Portugal (Zilhão 1998) and of Murujuga in Western Australia (McDonald 2015). In these circumstances, the engravings are on open view on rock piles across the landscape. Without the guidance of a traditional owner or custodian, how can one understand which sites or images are restricted and which ones are not?

\section{Discussion}

Archaeological theory on rock art and landscape archaeology uses qualitative and quantitative methods to evaluate the tangible features of places with rock art, such as visibility (site or motif locations) and size of the audience (number of participants according to the space available), to deduce potential site uses and functions of past rock art. While some of these features may have been used in the past to facilitate or restrict access to the sites, the complexity of human behaviour reminds us that there are aspects that are unpredictable and immeasurable such as cultural traditions, constraints and regulations. By exploring these questions in an ethnographic context, our aim was to determine how these aspects could affect our interpretations of the art and how understanding these processes can help in theory building.

In this paper, we have assessed a number of assumptions used in archaeology today in terms of their validity for rock art sites in the Barunga region of the Northern Territory, Australia. The only assumption that we can unequivocally endorse is the link between hidden images and restricted or private access to knowledge, as demonstrated by the sorcery image at Drupni. This link needs to be tested through further research.

Our research calls into question a number of assumptions that are core to contemporary archaeological method and theory. Specifically, it does not support the notion that a secluded location, or one that is difficult to access, is needed to restrict access to a site. Rather, site access is controlled by a plethora of cultural rules that are normalized throughout an individual's lifetime. Restriction to sites and knowledge can be achieved not only through difficult access and low visibility, but also through cultural rules. "Hidden' is a complex term, and also a mutable/dynamic one. Hidden sites do not need to be hidden, and the fact that may be are hidden from clear view (like Doria Gudaluk) doesn't mean that they cannot be visited by all. In fact, the word "hidden" is itself problematic. A site or a motif might be physically hidden for someone who is unfamiliar with a particular landscape or place, but easy to find for someone who is familiar with the landscape or the place even if the site is physically hidden. Sometimes a motif might be hidden because it is considered dangerous, and not necessarily because it is a secret/sacred image. In a similar way, sites that are visible and accessible from a landscape perspective can be subject to restricted access, regulated through social rules. Moreover, sites that appear to be hidden within the landscape, such as 
Doria Gudaluk, may be open access sites, although they may be closed for periods of time in relation to specific ceremonies. In this example, the major ceremonies are female-only, although there is also the possibility that male-only ceremonies occasionally were held close by, nor does our study support the notion that a site with high visibility within the landscape is likely to have open access. The site of Jerraewun is clearly visible within the landscape, and open for all to visit. However, it is closed when male-only ceremonies are in progress. These forms of controlled access are largely archaeologically invisible.

Taken together, the results of our study challenge the commonly held dichotomy between sacred/restricted access and secular/open access. Moreover, while all land is sacred, some places within the landscape are particularly potent, potentially dangerous. In addition, our research challenges the notion that visually dominating images located in an open part of a site will communicate solely public information. Such images may contain secret as well as public information, or be subject to gender restrictions on viewing, as at Doria Gudaluk. The constraints on access to sites that are described in this paper are archaeologically invisible, and thus hard to assess in a purely archaeological context. In addition, rock art production or the use of sites may involve touching the surface of the rock or rubbing motifs with ochre. As Ross and Davidson (2006:335) point out, such interactive performances are unlikely to leave a clear signature for archaeologists.

One of the great lessons of ethnoarchaeology is to be aware that social and cultural variation occurs through space and time. This awareness can provide insights to drive our research questions, even in contexts that are purely archaeological. For example, Davidson (1999) draws on ethnographic studies of Indigenous cultural traditions (Megaw 1983; Layton 1985, 1992; Morphy 1991) to demonstrate how symbolic values can vary across time within a single iconic tradition, in relation to Upper Palaeolithic rock art (see also Davidson 2012).

We should be focusing on rock art sites as they function within a wider cultural landscape, not just the sites themselves. Features that for European archaeologists seem to be important in the selection of sites, such as visibility and size, do not seem to be critical for Aboriginal people in the Barunga region. While archaeologists tend to interpret those features as signs reflecting intended audiences (whether public or private/secret), the selection of places by Aboriginal people is more likely to be related to the cultural significance of the place in relation to creation stories. The creation of rock art is less about controlling people's movements within the landscape, than about marking significant places where creation beings acted during the creation time and where they are still believed to remain today.

Finally, we identify the need for more ethnoarchaeological research into rock art. We need to question our assumptions if we aim to develop robust archaeological method and theory that explains the behaviours of past societies. Ethnoarchaeology assist in this. It can broaden our understandings of what is possible, so we do not simply take a western mindset and apply it to our interpretations of the past. In this study, ethnoarchaeological research has made it possible learn that access to sites and knowledge can be regulated not only through physical difficulties, remote locations and low visibility, but also through cultural rules that leave few interpretative clues for archaeologists. It has shown that motifs may have many meanings, and that meaning can be hidden in plain sight, as others have discussed (e.g. Munn 1983; Morphy 1991; Taylor 1996). It has demonstrated the importance of focusing on rock art sites as they exist within a wider cultural landscape, not just the sites themselves, which may-or 
may not — be the foci of power and/or ritual. Ethnoarchaeology has been misused in the past, through the enthusiastic but misguided application of Australian Aboriginal totemism to Palaeolithic cave art (e.g. Breuil and Lantier 1965), across thousands of years and thousands of kilometres. Consequently, the use of ethnographic analogy has been subject to considerable, valid critique (e.g. Ucko and Rosenfeld 1967; 124-127; Davidson 1988, 1995). Today, ethnoarchaeology is an under-utilized tool in a severely limited archaeological toolkit. The great value of ethnoarchaeology is that it can challenge our taken-for-granted assumptions and be used to develop theoretical models that can be tested against archaeological materials. Let us use all the tools in our archaeological toolkit. Our views are captured in Iain Davidson's (1999) acknowledgement of the career of Andrée Rosenfeld:

To hear her [Andrée Rosenfeld] talk about the archaeology of rock art, or to read her work, is to understand that, however difficult the study may be, there is hope that something can be said about rock art which does not fall into the obvious traps (Davidson 1999:130).

\begin{abstract}
Acknowledgements We are grateful to the traditional owners and custodians/junggayi who have guided our work in the Barunga region over three decades. When we started research at Barunga our principal teachers were Phyllis Wiynjorroc, Peter Manabaru, Paddy Babu and Lilly Willika. Over the years, we were also guided by Jack Chadum, Billy Lukanawi, Jimmy Wesan, Glen Wesan and Victor Hood. Today, we work most closely with traditional owners Esther Bulumbara, Ambrose Bulumbara, Gwyn Bulumbara and Elizabeth Coleman/Moreen, and with junggaji Nell Brown and Guy Rankin. We thank them for their continued friendship and for permission to publish the images used in this paper.
\end{abstract}

Funding Information Our research has been funded by Australian Research Council grants DP190102219 and DP0453101. Ines Domingo and Didac Roman have received support from HAR2016-80693-P funded by the Spanish Ministerio de Economía, Industria y competitividad and ERC CoG 2018 LArcHer project, funded by the European Research Council (ERC) under the European Union's Horizon 2020 research and innovation programme (grant agreement No 819404). The authors received financial support from the Ian Potter Foundation and the Australian Institute of Aboriginal and Torres Strait Islander Studies.

Open Access This article is licensed under a Creative Commons Attribution 4.0 International License, which permits use, sharing, adaptation, distribution and reproduction in any medium or format, as long as you give appropriate credit to the original author(s) and the source, provide a link to the Creative Commons licence, and indicate if changes were made. The images or other third party material in this article are included in the article's Creative Commons licence, unless indicated otherwise in a credit line to the material. If material is not included in the article's Creative Commons licence and your intended use is not permitted by statutory regulation or exceeds the permitted use, you will need to obtain permission directly from the copyright holder. To view a copy of this licence, visit http://creativecommons.org/licenses/by/4.0/.

\title{
References
}

Acevedo, A., Fiore, D., \& Ferrari, A. A. (2019). Rock art landscapes. A systematic study of images, topographies and visibility in south-central Patagonia (Argentina). Journal of Anthropological Archaeology, 56, 101101. 
Bahn, P. (2010). Accessibility: the public and the private. In Prehistoric rock art: polemics and progress (pp. 152-156). Cambridge: Cambridge University Press.

Balbín Behrmann, R., \& Bueno, P. (2009). Altamira, un siècle après: art paléolithique en plein air. L'Anthropologie, 113(3-4), 602-628.

Berndt, R., \& Berndt, C. (1999). The world of the first Australians: Aboriginal traditional life: past and present. Canberra: Aboriginal Studies Press.

Bourdier, C. (2013). Rock art and social geography in the Upper Paleolithic. Contribution to the socio-cultural function of the Roc-aux-Sorciers rock-shelter (Angles-sur-l'Anglin, France) from the viewpoint of its sculpted frieze. Journal of Anthropological Archaeology, 32(4), 368-382.

Bourdier, C., Fuentes, O., Pinçon, G., \& Baleux, F. (2017). Methodological contribution to the integrated study of European Palaeolithic rock art: The issue of the audience and the perceptibility of Roc-auxSorciers rock art (Angles-sur-l'Anglin, France). Quaternary International, 430, 114-129.

Bradley, R. (1997). Rock art and the prehistory of Atlantic Europe: signing the land. London: Routledge.

Bradley, R. (2000). An archaeology of natural places. London: Routledge.

Bradley, R. (2002). Access, style and imagery: the audience for prehistoric rock art in Atlantic Spain and Portugal, 4000-2000 BC. Oxford Journal of Archaeology, 21(3), 231-247.

Bradley, R., Criado Boado, F., Fábregas, \& Valcarce, R. (1994). Los petroglifos como forma de apropiación del espacio: algunos ejemplos gallegos. Trabajos de Prehistoria, 51(2), 159-168.

Brady, L. M., \& Bradley, J. (2014). Images of relatedness: patterning and cultural contexts in Yanyuwa rock art, Sir Edward Pellew Islands, SW gulf of Carpentaria, Northern Australia. Rock Art Research, 31(2), $157-176$.

Brady, L.M. \& Bradley, J. (2016). Who do you want to kill? Affectual and relational understandings at a sorcery rock art site in the southwest Gulf of Carpentaria, northern Australia. Journal of the Royal Anthropological Institute (N.S.), 22, 884-90.

Brady, L. M., \& Kearney, A. (2016). Sitting in the gap: ethnoarchaeology, rock art and methodological openness. World Archaeology, 48(5), 642-655.

Brady, L. M., Bradley, J., \& Kearney, A. (2016). Negotiating Yanyuwa rock art: relational and affectual experiences in the southwest Gulf of Carpentaria, northern Australia. Current Anthropology, 57(1), 2852.

Breuil, H. (1914). A propos des masques quaternaires. L'Anthropologie, 25, 420-422.

Breuil, H. (1952). Quatre cents siècles d' art parietal. París: Reed. Max Fourny.

Breuil, H., \& Lantier, R. (1965). The men of the old stone age. London: Harrap.

Chaloupka, G. (1985). Chronological sequence of Arnhem Land plateau rock art. In R. Jones (ed.), Archaeological Research in Kakadu National Park (pp. 260-80). Australian National Parks and Wildlife Service Special Publications 13: Canberra.

Chaloupka, G. (1993). Journey in time. The world's longest continuing art tradition. Sydney: Reed books.

Criado, F. (1993). Visibilidad e interpretación del registro arqueológico / the visibility and interpretation of the archaeological record. Trabajos de Prehistoria, 50(0), 39-56.

David, B., Geneste, M.-G., Whear, R. L., Delannoy, J.-J., Katherine, M., \& Gunn, R. G. (2011). Nawarla Gabarnmang, a 45,180 \pm 910 cal BP site in Jawoyn country, Southwest Arnhem Land plateau. Australian Archaeology, 73(1), 73-77.

Davidson, I. (1988). The naming of parts: Ethnography and the interpretation of Australian prehistory. In B. Meehan \& R. Jones (Eds.), Archaeology with ethnography: An Australian perspective (pp. 17-32). Canberra: Dept of Prehistory, Australian National University.

Davidson, I. (1995). Paintings, power, and the past: Can there ever be an ethnoarchaeology of art? Current Anthropology, 36(5), 889-892.

Davidson, I. (1999). Symbols by nature: animal frequencies in the Upper Palaeolithic of western Europe and the nature of symbolic representation. Archaeology in Oceania, 34(3), 121-131.

Davidson, I. (2012). What a carry on? Portable art and changes of symbolic meaning. L'art pléistocène dans le monde / Pleistocene art of the world / Arte pleistoceno en el mundo, Actes du Congrès IFRAO, Tarasconsur-Ariège, septembre 2010, $\mathrm{N}^{\circ}$ spécial de Préhistoire, Art et Sociétés, Bulletin de la Société Préhistorique Ariège-Pyrénées, LXV-LXVI, (pp. 268-269), CD: p. 559-1570.

Domingo, I., \& May, S. K. (2008). La pintura y su simbología en las comunidades de cazarecolectores de la Tierra de Arnhem. In J. Salazar, I. Domingo, J. Azkárraga, \& H. Bonet (Eds.), Mundos Tribales: Una Visión Etnoarqueológica (pp. 78-91). Museu de Prehistoria: Valencia.

Domingo, I., Fiore, D., \& May, S. (2008). Archaeologies of art: Time, place, and identity in rock art, portable art, and body art. In I. Domingo, D. Fiore, \& S. May (Eds.), Archaeologies of art: Time, place, and identity (pp. 15-27). Walnut Creek, CA: Left Coast Press. 
Domingo, I., May, S. K. \& Smith, C. (2016) Communicating through rock art: an ethnoarchaeological perspective. In O. Buchsenschutz, C. Jeunesse, C. Mordant \& D. VIALOU (dir.) Signes et communication dans les civilisations de la parole, (pp. 10-26). Paris, Édition électronique du CTHS.

Elkin, A. P. (1952). Cave paintings in southern Arnhem Land. Oceania, 22(4), 245-255.

Engelmark, R. \& Larsson, T.B. (2005). Rock art and environment: toward increased contextual understanding. In M. Santos and A. Troncoso (Eds), Reflexiones sobre arte rupestre: paisaje, forma y contenido (pp. 113-22). Tapa 33. Santiago de Compostela: Instituto de Estudios Galegos Padre Sarmiento.

Fairen, S. (2002). El paisaje de las primeras comunidades productoras en la cuenca del río Serpis (País Valenciano). Villena: Fundación José María Soler.

Fairen, S. (2004). Mobility, visibility and the distribution of schematic rock art in central Mediterranean Iberia. In F. Nicolucci \& S. Hermon (Eds.) Beyond the artifact. Digital interpretation of the past. Proceedings of CAA2004, Prato 13-17 April 2004 (pp. 152-155). Budapest: Archaeolingua.

Gillings, M. (2015). Mapping invisibility: GIS approaches to the analysis of hiding and seclusion. Journal of Archaeological Science, 62, 1-14.

Gunn, R. G., \& Whear, R. L. (2007). Tangtangjal cave revisited. The Artefact, 30, 16-28.

Gunn, R. G., Douglas, L. C., \& Whear, R. L. (2011). What bird is that? Identifying a probable painting of Genyornis newtoni in western Arnhem Land. Australian Archaeology, 73, 1-12.

Hartley, R. \& Vawser, A.M.W. (1998): Spatial behaviour and learning in the prehistoric environment of Colorado River drainage (south-eastern Utah), western North America. In C. Chippindale and P. Taçon (Eds.) The Archaeology of rock art (pp. 185-211). Cambridge, Cambridge University Press.

Hayward, J., Johnson, I., May, S., \& Taçon, P. (2018). Memorialization and the stencilled rock art of Mirarr Country. Northern Australia. Cambridge Archaeological Journal. DOI, 28(3), 361-378. https://doi. org/10.1017/S095977431800015X.

Jackson, G., \& Smith, C. (2005). Living and learning on aboriginal land. Decolonising archaeology in practice. In C. Smith \& H. M. Wobst (Eds.), Indigenous archaeologies: decolonising theory and practice (pp. 328-351). London: Routledge.

Jouteau, A., Feruglio, V., Bourdier, C., Camus, H., Ferrier, C., Santos, F., \& Jaubert, J. (2019). Choosing rock art locations: Geological parameters and social behaviors. The example of Cussac Cave (Dordogne, France). Journal of Archaeological Science, 105, 81-96.

Kearney, A., Brady, L. M., \& Bradley, J. (2017). A place of substance: stories of indigenous place meaning in the southwest Gulf of Carpentaria, northern Australia. Journal of Anthropological Research, 74(3), 360387.

Layton, R. (1985). The cultural context of hunter-gatherer rock art. Man: Journal of the Royal Anthropological Institute, 20(3), 434-453.

Layton, R. (1992). Australian rock art. A new synthesis. Melbourne: Cambridge University Press.

Lenssen-Erz, T. (2004). The landscape setting of rock-painting sites in the Brandberg (Namibia): infrastructure, Gestaltung, use and meaning. In C. Chippindale \& G. Nash (Eds.), Pictures in place. The figured landscapes of rock-art (pp. 131-149). Cambridge: Cambridge University Press.

Lenssen-Erz, T. (2008). Space and discourse as constituents of past identities - the case of Namibian rock art. In I Domingo, D. Fiore \& S. May, S. (Eds) Archaeologies of art: time, place, and identity (pp. 29-50). Walnut Creek, CA: Left Coast Press.

Lenssen-Erz, T. (2012). Rock art in context. Theoretical aspects of pragmatic data collection. In B. Smith, K. Helskog, \& D. Morris (Eds.), Working with rock art. Recording, presenting and understanding rock art using indigenous knowledge (pp. 47-58). Johannesburg: Wits University Press.

Leroi-Gourhan, A. (1964). Préhistoire de l'art Occidental. Paris: L. Mazenod.

Lorblanchet M. (2010). Art pariétal: grottes ornées du Quercy, Ed. Du Rouergue, Rodez

Macintosh, N. G. W. (1952). Paintings in Beswick Creek Cave, Northern Territory. Oceania, 22(4), $256-274$.

Macintosh, N. G. W. (1977). Beswick Creek cave two decades later: a reappraisal. In P. J. Ucko (Ed.), Form in indigenous art (pp. 191-197). Canberra: Australian Institute of Aboriginal Studies.

Maddock, K. (1971). Imagery and social structure at two Dalabon rock art sites. Anthropological Forum, II, 4, $444-463$.

Maddock, K. (1982). The Australian Aborigines. Ringwood: Penguin Books.

Martínez Garcia, J. (1998). Abrigos y accidentes geográficos como categorías de análisis en el paisaje de la pintura rupestre esquemática. El sudeste como marco, Arqueología Espacial, 19-20, 543-561.

May, S. K. (2008). Learning art, learning culture: art, education, and the formation of new artistic identities in Arnhem Land, Australia. In I. Domingo Sanz, S. May, \& D. Fiore (Eds.), Archaeologies of art: time, place and identity (pp. 171-194). Walnut Creek, CA: Left Coast Press.

May, S. K., \& Domingo I. (2010). Making sense of scenes. Rock Art Research, 27(1), 35-42. 
McDonald, J. (2015). I must go down to the seas again: or, what happens when the sea comes to you? Murujuga rock art as an environmental indicator for Australia's north-west. Quaternary International, $385,124-135$.

Megaw, J. V. S. (1983). The present past? A minimal view of ethnographic analogy and rock art. In M. Smith (Ed.), Archaeology at ANZAAS (pp. 279-292). Perth: Western Australian Museum.

Merlan, F. (1998). Caging the rainbow: places, politics, and aborigines in a north Australian town. Honolulu: University of Hawaii Press.

Morphy, H. (1991). Ancestral connections: art and an aboriginal system of knowledge. Chicago: University of Chicago Press.

Mulvaney, K. (1992). Who paints for a killing: Gurindji sorcery painting of Palngarrawuny. In J. McDonald \& I. P. Haskovec (Eds.), State of the art: regional rock art studies in Australia and Melanesia (pp. 216225). Melbourne: Australian Rock Art Research Association.

Munn, N.D. (1973). Walbiri iconography: graphic representation and cultural symbolism in a Central Australian society. Ithaca [NY]: Cornell University Press.

Nash, G., \& Chippindale, C. (2001). European landscapes of rock art. London and New York: Routledge.

Ouzman, S. (2005). The magical arts of a raider nation: central South Africa's Korana rock art. South African Archaeological Society Goodwin Series, 9, 101-113.

Pastoors, A., \& Weniger, G.-C. (2011). Cave art in context: methods for the analysis of the spatial organization of cave sites. Journal of Archaeological Research, 19(4), 377-400.

Reinach, S. (1903). L'art et la magie: à propos des peintures et des gravures de l'Âge du Renne. L'Anthropologie, 14, 257-266.

Rose, D. B. (1992). Dingo makes us human. Cambridge: Cambridge University Press.

Ross, J., \& Davidson, I. (2006). Rock art and ritual: an archaeological analysis of rock art in arid Central Australia. Journal of Archaeological Method and Theory, 13(4), 305-341.

Smith, C. (1992). Executive producer Jungayi. Caring for country. Documentary. Copyright held by Peter Manabaru.

Smith, C. (1999). Ancestors, place and people. In P. Ucko \& R. Layton (Eds.), The archaeology and anthropology of landscape (pp. 189-205). London: Routledge.

Smith, C. (2004). Country, kin and culture. Survival of an Australian Aboriginal community. Adelaide: Wakefield Press.

Smith, C., \& Jackson, G. (2008). The ethics of collaboration. Whose culture? Whose intellectual property? Who benefits? In C. Colwell-Chanthaphonh \& T. J. Ferguson (Eds.), Collaboration in archaeological practice: engaging descendent communities (pp. 171-191). Walnut Creek, CA: AltaMira Press.

Smith, C., Domingo, I., \& Jackson, G. (2016). Beswick Creek Cave six decades later: change and continuity in the rock art of Doria Gudaluk. Antiquity, 90(354), 1613-1626.

Smith, C., A. Kearney, A. Kotarba-Morley, C. Wilson, J. Grant, K. Pollard \& U. Saikia, with J. Willika (2020). Friday essay: voices from the bush - how lockdown affects remote communities differently. The Conversation. 15th May. https://theconversation.com/friday-essay-voices-from-the-bush-how-lockdownaffects-remote-indigenous-communities-differently-136953

Strecker, I. (1988). The social practice of symbolization: an anthropological analysis. London: Athlone Press.

Taçon, P.S.C. (1989). From rainbow snakes to 'X-Ray' fish: the nature of the recent rock painting tradition of western Arnhem Land, Australia. Unpublished PhD thesis. The Australian National University, Canberra.

Taçon, P. S. C. (1990). The power of place: cross-cultural responses to natural and cultural landscapes of stone and earth. In J. M. Vastokas (Ed.), Perspectives of the Canadian landscape: Native traditions (pp. 11-43). North York: Robarts Centre for Canadian Studies, York University.

Taçon, P. S. C. (1994). Socialising landscapes: the long-term implications of signs, symbols and marks on the land. Archaeology in Oceania, 29(3), 117-129.

Taylor, L. (1996). Seeing the inside: bark painting in Western Arnhem Land. Oxford: Clarendon Press.

Ucko, P., \& Rosenfeld, A. (1967). Palaeolithic cave art. London: Weidenfeld and Nicolson.

Whitley, D. (Ed.). (2001). Handbook of rock art research. Walnut Creek, CA: Altamira Press.

Wiynjorroc, P., Manaburu, P., Brown, N., \& Warner, A. (2005). We just have to show you: research ethics Blekbalawei. In C. Smith \& H. M. Wobst (Eds.), Indigenous archaeologies: decolonising theory and practice (pp. 316-327). London: Routledge.

Zilhão, J. (1998). The rock art of the Côa valley, Portugal: significance, conservation and management. Conservation and Management of Archaeological Sites, 2(4), 193-206.

Publisher's Note Springer Nature remains neutral with regard to jurisdictional claims in published maps and institutional affiliations. 


\section{Affiliations}

\section{Inés Domingo ${ }^{1} \cdot$ Claire Smith $^{2} \cdot$ Gary Jackson $^{2} \cdot$ Didac Roman $^{3}$}

1 Department of History and Archaeology ICREA, SERP, Universitat de Barcelona, Montealegre, 6-8, 08001 Barcelona, Spain

2 College of Humanities, Arts \& Social Sciences, Flinders University, GPO Box 2100, Adelaide, S.A. 5001, Australia

3 Departament d'Història Pre-EINA, Universitat Jaume I, Geografia i Art. Av. Vicent Sos Baynat, s/n, 12071 Castelló de la Plana, Spain 